\title{
STUDY OF POTENTIAL NEUROTOXIC EFFECTS OF ACRYLAMIDE ON THE CEREBELLUM IN ADULT ALBINO RATS
}

\author{
Aliaa M. Mahmoud*, Nadra K. Ali *, Ghada E. A. El mesallamy* and Nehad F. Mazen ** \\ Forensic Medicine and Clinical Toxicology*,Histology and cell biology ** Departments \\ Faculty of Medicine - Zagazig University - Egypt \\ Corresponding author: Dr. Aliaa Mohammad \\ Email: Marwan_feb2010@hotmail.com \\ Mobile: 01003398984
}

\begin{abstract}
Background: Acrylamide (ACR) is an industrial pollutant, an exposure to acrylamide via different routes causes selective neurotoxicity. Aim of the Work: This work was performed to study potential neurotoxic effects of acrylamide on the cerebellum in adult albino rats by evaluation of neurobehavioral functional observational tests (gait score, landing hind limb foot splay), histopathological and immunhistochemichal testing of cerebellum. Materials and Methods: This study was carried out on 48 adult male albino rats which divided into 4 equal groups; GroupI (negative control group), Group II (positive control group) GroupIII (low dose acrylamide): Subdivided into two equal subgroups( III a\& IIIb ) : each rat was gavaged orally with daily dose of $8.5 \mathrm{mg} / \mathrm{kg}$ acrylamide for $4 \& 8$ weeks respectively. Group IV (high dose acrylamide): Subdivided into two equal subgroups( IV a\& IV b ) : each rat was gavaged orally with daily dose of $17 \mathrm{mg} / \mathrm{kg}$ acrylamide for $4 \& 8$ weeks respectively. Results: There was a significant increase in both mean rank and mean values of gait scores and landing hind limb foot splay of both treated groups as compared to those of control groups. There was a strong positive correlation between foot splay and gait score, Microscopic examination of H\&E stained of cerebellum of both treated groups showed loss of purkinjie cells, ACR affections were dose and time dependent. Silver stained cerebellar sections of rats received low dose for 4 weeks showed loss of some Purkinje cells, other rats received low dose for 8 weeks or high dose showed loss of most Purkinjie cells and the fibers of the white matter were seen with progressive fragmentation. Immunolocalization of Glial Fibrillary Acidic Protein (GFAP) in the cerebellum of treated groups showed progressive distribution of GFAP-positive astrocytes which was dose and time dependent. There was a strong positive correlation between area percentage and landing hind limb foot splay, a moderate positive correlation between area percentage and gait score. Conclusion: Acrylamide has a neurotoxic effect clarified by impairment of gait score and increase in landing hind limb foot splay. The abnormal neurobehavioral functional observational tests were associated to cerebellar histopathological changes in the form of selective loss of purkinjie cell, axonapathy and gliosis. Recommendation: it is recommended to increase public awareness about the health impact of exposure to acrylamide.
\end{abstract}

Key Words: Acrylamide; cerebellum; gait score; foot splay and GFAP.

\section{INTRODUCTION}

The chemical intoxication in general population have been increased by both industrial activities that heavily introduced an array of new chemicals into the environment, and increasing the frequency of using these chemicals in our everyday lives (Santhanasapathy et al., 2015). Acrylamide (ACR) is an industrial pollutant that is extensively generated during such industrial activities. Routes of exposure to ACR include ingestion, inhalation, and skin contact. However, the direct consumer exposure to ACR is by ingestion of high carbohydrate foods such as potato, crisps, chips, roasted cereals, and breads (Kumar et al., 2014). In latest years, world health organization (WHO) pronounced that ACR is formed in fried and baked starchy foods during cooking. Acrylamide is formed in foods, during heating in ovens, on a frying pan or by microwaves. This announcement has significantly raised public worries over ACR potential health risk. By growing sources of ACR exposure to the over-all public, the need for understanding the toxicological risk related to such exposure became in high demand (Motamedshariaty et al., 2014).

Acrylamide belongs to the group of chemicals which have no reliably identifiable 'threshold' of effects, meaning that, very low 
concentrations will also result in very low risks, but not in zero risk (Erkekoglu and Baydar., 2010). Occupational exposure of human and experimental intoxication of laboratory animals with ACR are thought to produce a neurotoxic syndrome characterized by skeletal muscle weakness, and ataxia which is attributed to functional disturbance in cerebellum, however, the mechanism of ACR induced cerebellar dysfunction is not completely known. (Shi et al., 2012).

Aim of the Work: This work was performed to study potential neurotoxic effects of acrylamide on the cerebellum in adult albino rats by evaluation of neurobehavioral functional observational tests (gait score, landing hind limb foot splay), histopathological and immunhistochemichal testing of cerebellum.

\section{MATERIAL AND METHODS}

\section{A- Material: Acrylamide}

Acrylamide monomer dry crystals (C3H5NO, $>99.9 \%$ purity, was purchased from Sigma Aldrich (St. Louis,MO).

\section{B-Kits}

Detection kit: the primary antibodies for GFAP were a mouse monoclonal antibody The study was carried out on 48 adult male albino rats with average weight of 150-200 grams. They were obtained from the animal house of Zagazig Scientific \&Medical Research Center of the Faculty of Medicine, Zagazig University.

The study had been designed in the Faculty of Medicine, Zagazig University. Ethical consideration of experimental animals were according to recommendations of the national institutes of health guide for care and use of lab animals (Institute of laboratory animal resources, 2011).

Study design:

Rats were randomly divided into four equal groups,

: Group I: (negative control group) subdivided in to two equal sub groups used to determine the basic values of tested parameters. Group II:

(Positive control group): subdivided into: two equal subgroups (Group IIa and group IIb) each rat gavaged orally with $(5 \mathrm{ml} / \mathrm{kg})$ saline $(0.9 \%)$ (Solvent of ACR) once daily (5 times per week) for 4 and 8 weeks respectively. Group III: Low dose acrylamide $(8.5 \mathrm{mg} / \mathrm{kg}$ ) group subdivided into two equal groups (Group IIIa and group IIIb) each rat gavaged orally with ACR at dose of $(8.5 \mathrm{mg} / \mathrm{kg}$ body weight) once daily (1/20 of $\mathrm{LD}_{50)}$ (Erkekoglua and Baydar, 2014), dissolved in $0.9 \%$ saline and administrated at $(5 \mathrm{ml} / \mathrm{kg})$ once daily (5 times per week) for 4 and 8 weeks respectivelyGroup IV: High dose acrylamide $(17 \mathrm{mg} / \mathrm{kg}$ group subdivided into two equal groups (group IVa and group IVb) each rat gavaged orally with ACR at dose of $(17 \mathrm{mg} / \mathrm{kg}$ body weight) once daily (1/10 of $\left.\mathrm{LD}_{50}\right)$

(Erkekoglua and Baydar, 2014), dissolved in $0.9 \%$ saline and administrated at $(5 \mathrm{ml} / \mathrm{kg})(5$ times per week) for 4 .and 8 weeks respectively. At the end of fourth and eighth week of the study, 6 rats from each group were subjected to: Neurobehavioral functional observational tests, histopathological and immunohistochemical testing of cerebellar tissue.

\section{B-Methods:}

\section{1-Neurobehavioral functional observational} tests:

A-Gait score: Each rat was placed in an open field and observed for 3 minutes. Gait scores were assigned from one to four according to the criteria of numerical gait score (Lehning et al., 2002), (a) represents a normal gait. (b) Represents a slightly abnormal gait (slight ataxia, hopping gait and foot splay).-(c) represents a moderately abnormal gait (obvious ataxia and foot splay with limb abduction during ambulation).-(d) represents a severely abnormal gait (inability to support body weight and foot splay)( fig. I a,b ,c ,d).

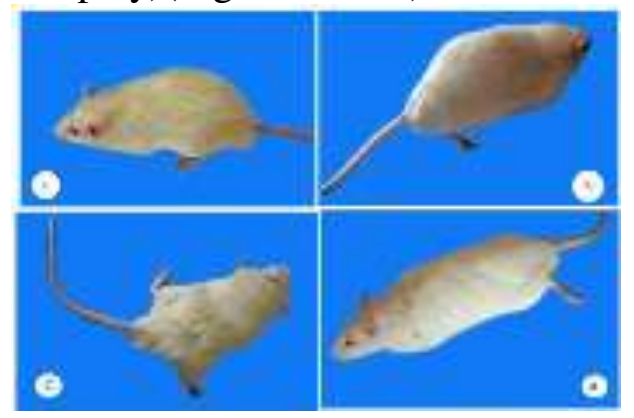


(fig.I).Observational gait score test: (a) represents normal gait. (b) Represents slight abnormal gait, (c) represents moderate abnormal gait. (d) Represents sever abnormal gait.

\section{B-Landing hind limb foot splay}

Landing hind limb foot splay was performed as previously described by LoPachin et al. (2002). to assess hind limb foot splay, the hind feet were inked and animals were held above and parallel to white paper surface at approximately $20 \mathrm{~cm}$ in height. Rats were dropped on the paper and the distances from the center of the right and left heels were measured and recorded (Fig.II)

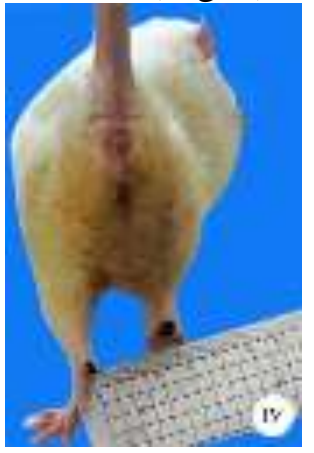

Fig.II

Measuring distance between the centre of right and left heel of the rat in hind limb foot splay test.

\section{2-Histopathological Examination:}

\section{A-Hematoxylin and Eosin Stains:}

Samples from cerebellum were routinely processed, embedded in paraffin blocks and sectioned at $5 \mu$ thick sections. Sections were stained with haematoxylin and eosin and examined by light microscope (Bancroft and Stevens, 1996).

\section{B- Silver Stain}

The nerve fibers are sensitized with a silver solution. The sections are treated with ammoniacal silver, and then reduced to a visible metallic silver Axons, neurofibrillary tangles and senile plaques with yellow to brown background appeared black (De olmas et al.,1994).

\section{C-Immunohistochemical Stain:}

According to (Coons and Kaplan, 2009). Immunostaining was performed using the
Avidin-biotin peroxidase technique for localization of glial fibrillary acidic protein (GFAP) using mouse monoclonal antibody of immunoglobulin $G$ type, designed for the specific localization of GFAP in cerebellum

\section{B-Morphological analysis:}

Non-overlapping fields from each rat were selected indiscriminately and analyzed for the area percentage of optical density of immune reaction of GFAP using NIH Image J (v1.50) image analysis software. (papadopulos et al ., 2007).

Results:

I -Neurobehavior functional observational tests:

\section{-Control groups}

There were a non-significant differences in the mean values of all studied parameters (p>0.05) between -ve and +ve control groups so; matched positive control group was used for comparison with the other groups

-Treated groups: A-Objective gait score: Abnormal gait were observed in both ACR treated groups. These gaits showed an aggravating tendency as the treatment period progressed and dose is increased. However, no abnormal change was observed in rats in the control groups Fig.III (a,b,c,d). (Table 1) showed a significant difference in mean rank values of gait score between positive control groups and treated groups all over the study by Kruskal-Wallis statistical test.

(Table 2) statistical analysis by Pairwise MannWhitney test revealed that, the mean rank values of gait score was significantly increased in ACR treated groups for either 4 or 8 weeks when compared with those of corresponding age control groups $(\mathrm{p}<0.001)$. In low dose groups :when comparing the mean rank values of gait score of rats after 4 weeks (groupIIIa) with those after 8 weeks(groupIIIb), it showed a significance increase in the mean rank value of gait score of (groupIIIb) $(\mathrm{p}<0.001)$. in high dose acrylamide groups: when comparing the mean rank values of gait score of rats after 4 weeks (groupIVa) with those after 8 weeks(groupIVb), it showed a significance increase in the mean rank value of gait score of 
(groupIVb) $(\mathrm{p}<0.001)$. After 4 weeks of the study: - There was a significance increase in the mean rank values of gait score of rats received high dose ACR (group IVa) $(\mathrm{p}<$ 0.001 ) when compared with those of low dose ACR (group IIIa) - After 8 weeks of the study: There was a significance increase in the mean rank values of gait score of rats received high dose ACR (group IVb) ( $<<$ 0.001) when compared with those of low dose ACR (group IIIb).

B-Landing hind limb foot splay :There was a significant difference in mean values of landing hind limb foot splay between all groups by ANOVA test all over the study $(\mathrm{p}<$ 0.001)(Table3) . Bonferroni's post hoc statistical test (Table4) revealed that, the mean values of landing hind limb foot splay were significantly increased in rats received ACR for either 4 or 8 weeks when compared with those of the corresponding age control groups $(\mathrm{p}<$ 0.001). In low dose ACR groups: when comparing the mean values of landing hind limb foot splay after 4 weeks in group (IIIa) with those after 8 weeks (group IIIb) there was a significance increase in the mean value of landing hind limb foot splay in (group IIIb) $(\mathrm{p}<$ 0.001) .). In high dose ACR groups: when comparing the mean values of landing hind limb foot splay of rats after 4 weeks in (group IVa) with those after 8 weeks, there was a significance increase in the mean value of landing hind limb foot splay of group (IVb) $(\mathrm{p}<$ 0.001). After 4 weeks of the study:-when comparing the mean values of landing hind limb foot splay of rats

received low dose ACR(IIIa) with those received high dose (IVa) there was a significance increase in the mean value of landing hind limb foot play of those received high dose $(p<0.001)$ After 8 weeks of the study: -when comparing the mean values of landing hind limb foot splay of rats received low dose ACR (IIIb)with those of high dose $\mathrm{ACR}(\mathrm{IVb})$ there was a significance increase in the mean value of landing hind limb foot splay of those received high dose $(p<0.001)$.
2-Area percentage of the affected cerebellar tissue: There was a non-significant difference in mean values of area percentage of the affected cerebellar tissue between positive control groups and ACR treated groups by ANOVA Test. ( $\mathrm{P}>0.05)$ (Table5).

3--The relationship between landing hind limb foot splay and gait score: Pearson correlation coefficient statistical test was computed to evaluate the relationship between landing hind limb foot splay and gait score. Then between each of them and area percentage of the affected cerebellar tissue of the rats. (Table 6)showed there was a strong positive correlation between hind limb foot splay and gait score represented as, increases in the landing hind limb foot splay were correlated with increases in the gait score $(r=.931)($. There was a strong positive correlation between foot splay and area percentage $(\mathrm{r}=.581)$ and a moderate correlation between gait score andarea percentage respectively $(\mathrm{r}=.331$. $)(\mathrm{P}<$ 0.001) (Table7)

-Prediction of the extent of structural cerebellar lesion induced by acrylamide in rats based on changes in hind limb foot splay and gait score: A multiple linear regression was calculated to predict the extent of structural cerebellar lesion induced by acrylamide in rats based on changes in hind limb foot splay and gait score.It was found that, the area percentage increased by $8.939 \%$ for each one degree increase in the gait score , and $5.942 \%$ for each $1 \mathrm{~cm}$ increase in the hind limb foot splay and a significant regression was found

\section{5-Histopathological Results:}

\section{Light microscopic examination of:}

(A) Hematoxylin and Eosin (H\&E) stained cerebellar sections of control groups showed normal histological cerebellar cortex structure in the form of lightly-stained outermost molecular layer, deeply-stained granular layer and Purkinje layer in-between(Figure1). Light Microscopic examination of $\mathrm{H} \& \mathrm{E}$ stained cerebellar sections of rats received $(8.5 \mathrm{mg} / \mathrm{kg}$ ACR) for 4 weeks (group IIIa), revealed prominent perineural spaces around cells in the molecular layer, Purkinje cell layer, and 
granular layer. Some Purkinje cells appeared with abnormal morphology, they appeared to have dark stained nuclei(Figure 2), while administration of the same dose for longer duration (8 weeks) in (group IIIb) result in more prominent histopathological changes in the form of loss of some of Purkinje cells(Figure 3). These changes progressed on administration of higher dose of $(17 \mathrm{mg} / \mathrm{kg}$ ACR) for either 4 or 8 weeks (group IVa, IVb) in the form of selective loss of most of Purkinjie cells(Figure 4\&5).

B-Silver stained cerebellar sections of control groups(Ia,I b, IIa, IIb) showed the three layers of cerebellar cortex. Brownish dendritic branches of Purkinje cells were seen in the molecular layer. Purkinje cell layer contained large flask-shaped Purkinje cells .Blackened fibers appeared in the Purkinje cell and granular layer (Figure 6). While microscopic examination of silver stained cerebellar sections of group IIIa (received ACR at dose of $8.5 \mathrm{mg} / \mathrm{kg}$ body weight for 4 weeks) showed loss of some Purkinje cells (Figure7) in addition, other treated groups (IIIb, IVa,IVb) (received ACR at dose of $8.5 \mathrm{mg} / \mathrm{kg}$ body weight for 8 weeks, $17 \mathrm{mg} / \mathrm{kg}$ ACR for 4 and 8 weeks respectively) showed loss of most Purkinje cells and the fibers of the white matter were seen also with progressive fragmentation that indicated obvious axon degeneration (Figure 8,9\&10)

\section{C-Immunohistochemical Staining:}

Light microscopic examination for immunolocalization of GFAP in the cerebellum of the control groups showing two characteristic patterns of brown glial processes; in the molecular layer, they are perpendicular to the surface, almost parallel to each other, and called Bergmann-glia or modified astrocytes. In granular layer, true astrocytes form a dense, irregular system. The end-feet of the Bergmannglia are visible on the meningueal surface (Figiure11).. Immunolocalization of GFAP in the cerebellum of groups IIIa and IIIb (received ACR at dose of $8.5 \mathrm{mg} / \mathrm{kg}$ bw for 4 and 8 weeks respectively) showed GFAPpositive astrocytes in the molecular layer, granular layer and white matter(Figure12\&13), whileimmunolocalizatio of GFAP in the cerebellum of rats received the higher dose for same periods in groups IVa ,IVb (received ACR at dose of $17 \mathrm{mg} / \mathrm{kg}$ for 4 and 8 weeks respectively)showed more abundant distributionof GFAP-positive astrocytes in all layers; molecular, granular and white mater(Figure14\&15).

Table (1): Statistical comparison between positive control groups and low\&high dose acrylamide treated groups as regard gait score after $4 \& 8$ weeks of the study by Kruskal-Wallis Test.

\begin{tabular}{|c|c|c|c|c|c|c|c|c|}
\hline \multirow{3}{*}{ Groups } & \multicolumn{2}{|c|}{$\begin{array}{c}\text { Positive Control } \\
\text { groups } \\
\text { n=12 }\end{array}$} & \multicolumn{2}{|c|}{$\begin{array}{c}\text { Low dose ACR } \\
(8.5 \mathrm{mg} / \mathrm{kg}) \text { groups } \\
\mathrm{n}=12\end{array}$} & \multicolumn{2}{|c|}{$\begin{array}{c}\text { High dose ACR } \\
(17.5 \mathrm{mg} / \mathrm{kg}) \text { Groups } \\
\mathrm{n}=12\end{array}$} & \multirow[t]{2}{*}{$\mathbf{H}$} & \multirow[t]{2}{*}{$\mathbf{P}$} \\
\hline & (IIa) & (IIb) & (IIIa) & (IIIb) & (IVa) & (IVb) & & \\
\hline & $\begin{array}{c}4 \\
\text { weekss }\end{array}$ & $\begin{array}{c}8 \\
\text { weeks }\end{array}$ & $\begin{array}{c}4 \\
\text { weeks }\end{array}$ & $\begin{array}{c}8 \\
\text { weekss }\end{array}$ & $\begin{array}{c}4 \\
\text { weekss }\end{array}$ & $\begin{array}{c}8 \\
\text { weeks }\end{array}$ & 32.18 & $<0.001 * *$ \\
\hline
\end{tabular}




\begin{tabular}{ccccccc} 
Gait & $\begin{array}{c}\text { Mean } \\
\text { rank }\end{array}$ & $\begin{array}{c}\text { Mean } \\
\text { rank }\end{array}$ & $\begin{array}{c}\text { Mean } \\
\text { rank }\end{array}$ & $\begin{array}{c}\text { Mean } \\
\text { rank }\end{array}$ & $\begin{array}{c}\text { Mean } \\
\text { rank }\end{array}$ & $\begin{array}{c}\text { Mean } \\
\text { rank }\end{array}$ \\
\cline { 2 - 7 } & 7.50 & 7.50 & 14.7 & 23.17 & 26.00 & 32.18 \\
\hline
\end{tabular}

** Highly significant $\mathbf{p}<0.001$

Number of rats in each subgroup $=6$ rats.

Table (2):Pairwise Mann-Whitney test for comparison between positive control groups and low\&high dose acrylamide treated groups as regard gait score after $4 \& 8$ weeks of the tudy.

\begin{tabular}{|c|c|c|c|c|c|c|}
\hline \multirow{3}{*}{ Gait score } & \multicolumn{2}{|l|}{$\begin{array}{l}\text { Postive control } \\
\text { groups }\end{array}$} & \multicolumn{2}{|l|}{$\begin{array}{l}\text { Low dose ACR } \\
(8.5 \mathrm{mg} / \mathrm{kg}) \\
\text { groups }\end{array}$} & \multicolumn{2}{|c|}{$\begin{array}{l}\text { High dose ACR } \\
(17 \mathrm{mg} / \mathrm{kg}) \\
\text { Groups }\end{array}$} \\
\hline & $n=12$ & & $\mathrm{n}=12$ & & $\mathrm{n}=12$ & \\
\hline & $\begin{array}{l}4 \text { weeks } \\
\text { (IIa) }\end{array}$ & $\begin{array}{l}8 \text { weeks } \\
\text { (IIb) }\end{array}$ & $\begin{array}{l}4 \text { weeks } \\
\text { (IIIa) }\end{array}$ & $\begin{array}{l}8 \text { weeks } \\
\text { (IIIb) }\end{array}$ & $\begin{array}{l}4 \text { weeks } \\
\text { (IVa) }\end{array}$ & $\begin{array}{l}8 \text { weeks } \\
\text { (IVb) }\end{array}$ \\
\hline IVb & & $<0.001 * *$ & $<0.001 * *$ & $<0.001 * *$ & $<0.001 * *$ & \\
\hline IVa & $<0.001 * *$ & & $<0.001 * *$ & $>0.05 \#$ & & \\
\hline$\overline{\text { IIIb }}$ & & $<0.001 * *$ & $<0.001 * *$ & & & \\
\hline IIIa & $<0.001 * *$ & & & & & \\
\hline
\end{tabular}

\#Non significant $\mathbf{P}>0.05$

** Highly significant $\mathbf{p}<0.001$.

Number of rats in each subgroup $=6$ rats

Table (3): Statistical comparison between positive control groups and low\&high dose acrylamide treated groups as regard landing hind limb foot splay after $4 \& 8$ weeks of the study by ANOVA test

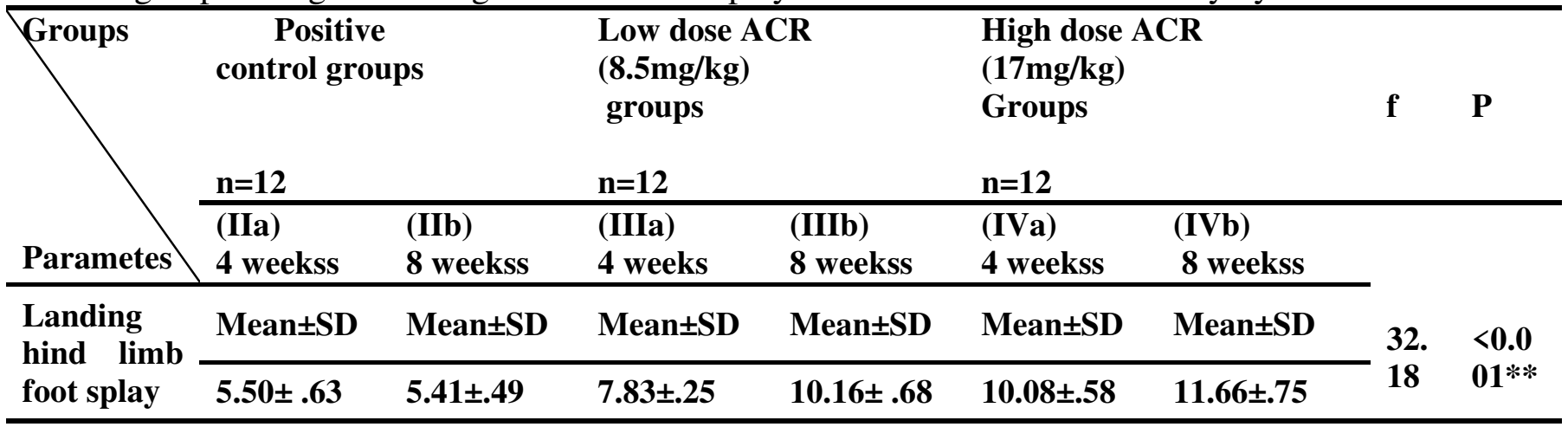

SD: Standard deviation.

** Highly significant $\mathbf{p}<0.001$

Number of rats in each subgroup $=6$ rats

Table (4): Bonferroni's post hoc test for comparison between positive control groups and low \&high dose acrylamide treated groups as regard landing hind limb foot splay after $4 \& 8$ weeks of the study.

\begin{tabular}{llll}
\hline Landing hind $\begin{array}{lll}\text { Postive } \\
\text { control group }\end{array}$ & Low dose ACR & High dose ACR \\
limb foot splay & $(8.5 \mathrm{mg} / \mathrm{kg})$ & $(17 \mathrm{mg} / \mathrm{kg})$ \\
& groups & groups \\
& $\mathrm{n}=12$ & $\mathrm{n}=12$ \\
\hline
\end{tabular}




\begin{tabular}{|c|c|c|c|c|c|c|}
\hline & $\begin{array}{l}\text { (IIa) } \\
4 \text { weeks }\end{array}$ & $\begin{array}{l}\text { (IIb) } \\
8 \text { weeks }\end{array}$ & $\begin{array}{l}\text { (IIIa) } \\
4 \text { weeks }\end{array}$ & $\begin{array}{l}\text { (IIIb) } \\
8 \text { weeks }\end{array}$ & $\begin{array}{l}\text { IVa) } \\
4 \text { weeks }\end{array}$ & $\begin{array}{l}\text { (IVb) } \\
8 \text { weeks }\end{array}$ \\
\hline IVb & & $<0.001 * *$ & $<0.001 * *$ & $<0.001 * *$ & $<0.001 * *$ & \\
\hline IVa & $<0.001 * *$ & & $<0.001 * *$ & $>0.05 \#$ & & \\
\hline IIIb & & $<0.001 * *$ & $<0.001 * *$ & & & \\
\hline IIIa & $<0.001 * *$ & & & & & \\
\hline
\end{tabular}

\#Non significant $\mathbf{P}>0.05$.** Highly significant $\mathbf{p}<0.001$.

Number of rats in each subgroup $=6$ rats

Table (5): Statistical comparison among positive control groups and low \&high dose acrylamide treated groups as regard area percentage of affected cerebellar tissues after $4 \& 8$ weeks of the study by ANOVA test.

\begin{tabular}{|c|c|c|c|c|c|c|c|c|}
\hline \multirow{3}{*}{ Groups } & \multicolumn{2}{|c|}{$\begin{array}{l}\text { Positive } \\
\text { control group }\end{array}$} & \multicolumn{2}{|c|}{$\begin{array}{l}\text { Low dose ACR } \\
(8.5 \mathrm{mg} / \mathrm{kg}) \\
\text { groups }\end{array}$} & \multicolumn{2}{|c|}{$\begin{array}{l}\text { High dose ACR } \\
(17 \mathrm{mg} / \mathrm{kg}) \\
\text { groups }\end{array}$} & \multirow{2}{*}{$\mathbf{F}$} & \multirow{2}{*}{$\mathbf{P}$} \\
\hline & $\begin{array}{l}\text { (IIa) } \\
4 \text { weeks }\end{array}$ & $\begin{array}{l}\text { (IIb) } \\
8 \text { weeks }\end{array}$ & $\begin{array}{l}\text { (IIIa) } \\
4 \text { weeks }\end{array}$ & $\begin{array}{l}\text { (IIIb) } \\
8 \text { weeks }\end{array}$ & $\begin{array}{l}\text { (IVa) } \\
4 \text { weeks }\end{array}$ & $\begin{array}{l}\text { (IVb) } \\
8 \text { weeks }\end{array}$ & & \\
\hline & Mean \pm SD & Mean \pm SD & Mean \pm SD & Mean \pm SD & Mean \pm SD & $\begin{array}{l}\text { Mean } \pm S \\
\text { D }\end{array}$ & \multirow{2}{*}{1.168} & \multirow{2}{*}{$.348 \neq$} \\
\hline $\begin{array}{l}\text { Cerebellar area } \\
\text { percentage }\end{array}$ & $26.65 \pm 1.01$ & $24.15 \pm 1.12$ & $30.54 \pm 1.7$ & $33.35 \pm 1.0$ & $36.85 \pm 1.07$ & $\begin{array}{c}35.12 \pm \\
4.71 \\
\end{array}$ & & \\
\hline
\end{tabular}

SD: Standard deviation.\#. Non significant $p>0.05$..Number of rats in each subgroup= 6 rats.

Table (6): Pearson's correlation coefficients(r) of the tested parameters (hind limb foot splay, gait score\&area percentage).

\begin{tabular}{|c|c|c|c|}
\hline paramete & & Area percentage & Gait score \\
\hline Hind limb & Foot Splay & . $\mathrm{r}=. \mathbf{5 8 1} \approx$ & $r=.931 ¥$ \\
\hline Splay & & . & \\
\hline area_percenta & & & $. \mathrm{r}=.331 \approx$ \\
\hline
\end{tabular}

$¥$ strong correlation

$\approx$ moderate correlation.

Table (7): Multiple linear regression relations of the tested parameter (area percentage, hind limb foot splay\& gait score).

\begin{tabular}{|c|c|c|c|c|}
\hline \multirow[b]{2}{*}{ parameters } & Cerebellar area percentage & \multirow{2}{*}{ R square } & \multirow{2}{*}{$\mathbf{F}$} & \\
\hline & Coefficient \% & & & $\mathbf{P}$ \\
\hline Hind limb foot splay & 5.942 & 0.334 & 8.261 & $<0.001$ \\
\hline Gait score & 8.939 & & & \\
\hline
\end{tabular}

** Highly significant $\mathrm{p}<0.001$. 


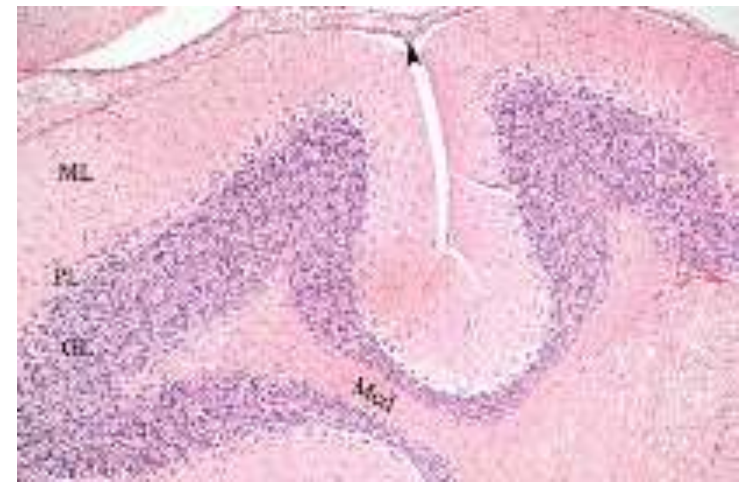

Fig (1)

Fig (3)

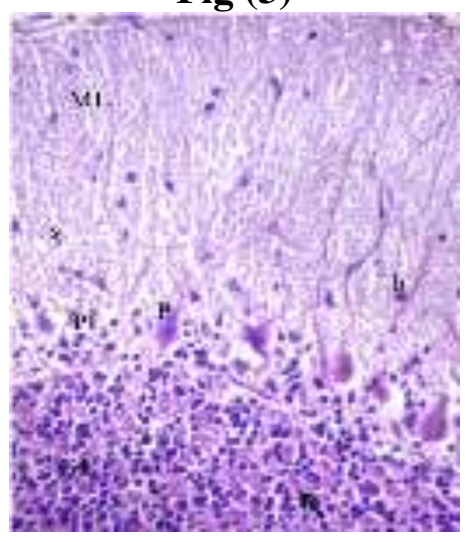

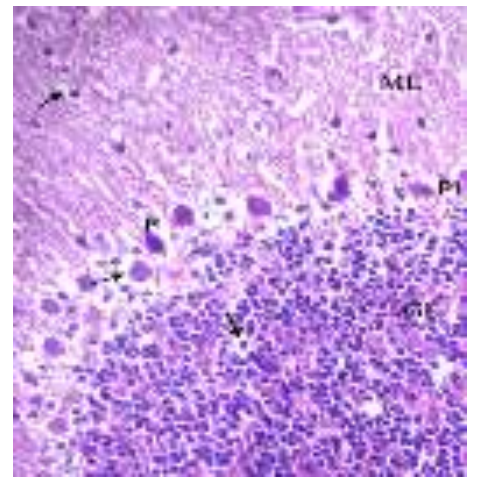

Fig (2)

Fig (4)

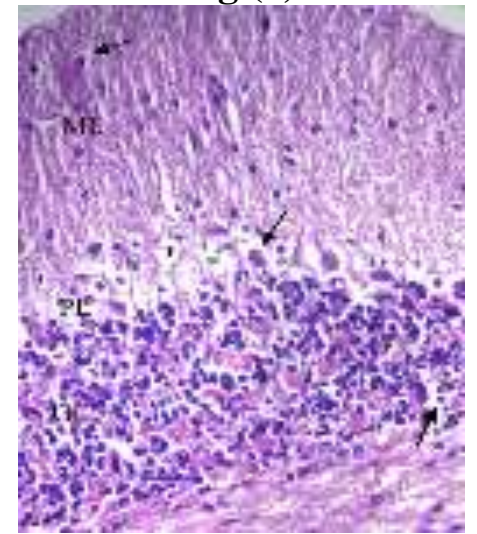

Fig (5)

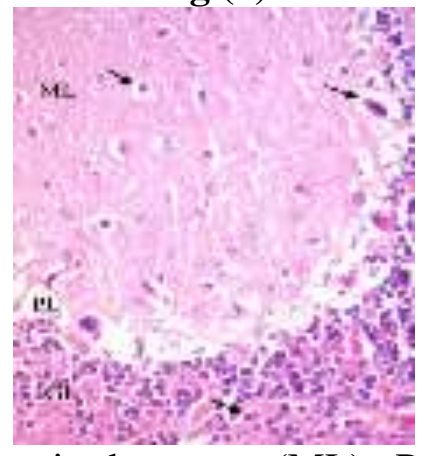

Fig. (1): A photomicrograph of a section in the cerebellum from a rat of positive control group showing pia mater (arrow head). The cerebellar cortex; molecular layer (ML), deeply-stained granular layer (GL) and Purkinje layer (PL) inbetween. Deep in the granular layer, the medulla (Med) appears lightly-stained. [H\&E, $\times 100]$

Fig. (2): A photomicrograph of a section in the cerebellum from a rat of group IIIA (received ACR at dose of $8.5 \mathrm{mg} / \mathrm{kg}$ body weight for 4 weeks) showing prominent perineural spaces (arrow) around cells in the molecular layer
(ML), Purkinje cell layer (PL), and granular layer (GL). Some Purkinje cells (P) appeared to have dark stained nuclei. [H\&E, $\times 100]$

Fig. (3): A photomicrograph of a section in the cerebellum from a rat of group IIIB (received ACR at dose of $8.5 \mathrm{mg} / \mathrm{kg}$ body weight for 8 weeks) showing loss of some Purkinje cells. Prominent perineural spaces (arrow) are seen in the molecular (ML), Purkinje cell (PL), and granular (GL) layers.

[H\&E, $\times$ 400] 
Fig. (4): A photomicrograph of a section in the cerebellum from a rat of group IVA (received ACR at dose of $17 \mathrm{mg} / \mathrm{kg}$ body weight for 4 weeks) showing loss of most Purkinje cells leaving empty spaces $(*)$. Prominent perineural spaces (arrow) are seen in the molecular (ML), Purkinje cell (PL), and granular (GL) layers. Wide perivascular spaces (zigzag arrow) were also noticed.

[H\&E, $\times$ 400].

Fig. (5): A photomicrograph of a section in the cerebellum from a rat of group IVB (received ACR at dose of $17 \mathrm{mg} / \mathrm{kg}$ body weight for 8 weeks) showing loss of most Purkinje cells leaving empty spaces.. $\quad[\mathrm{H} \& \mathrm{E}, \times 400]$
Fig. (6a)

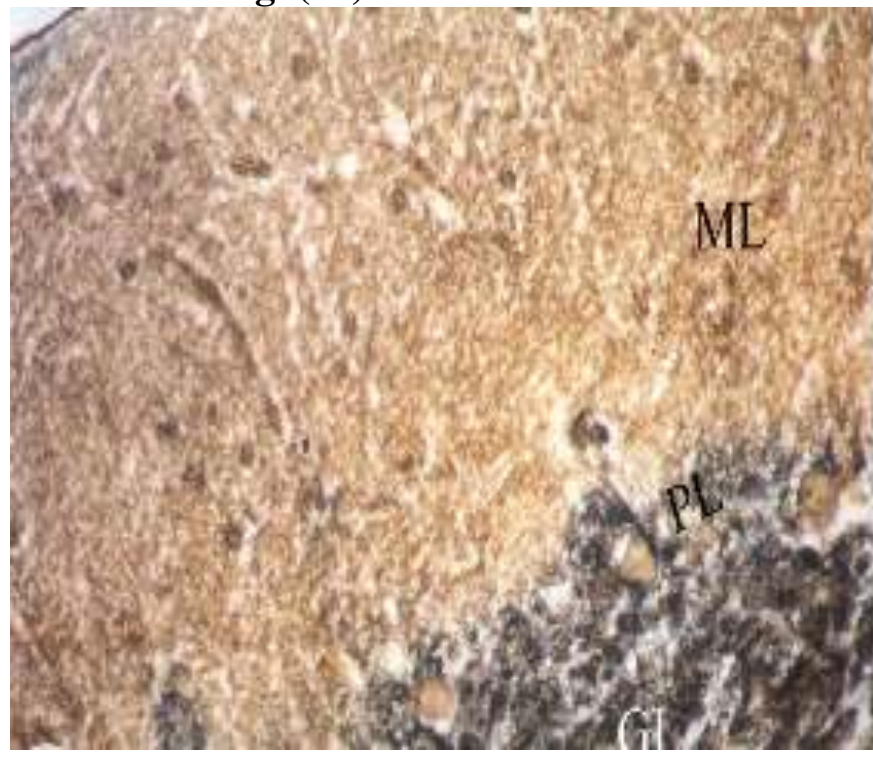

$\operatorname{Fig}(7 \mathbf{a})$
Fig.(6b)

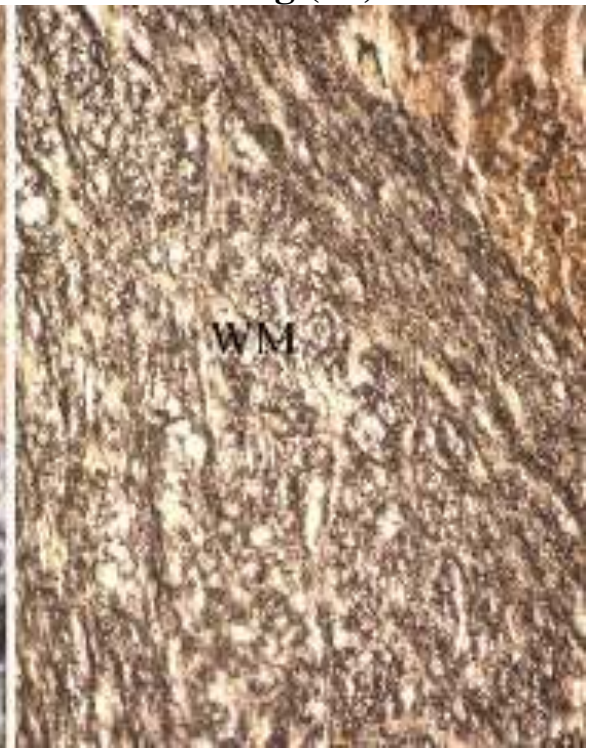

$\operatorname{Fig}(7 b)$

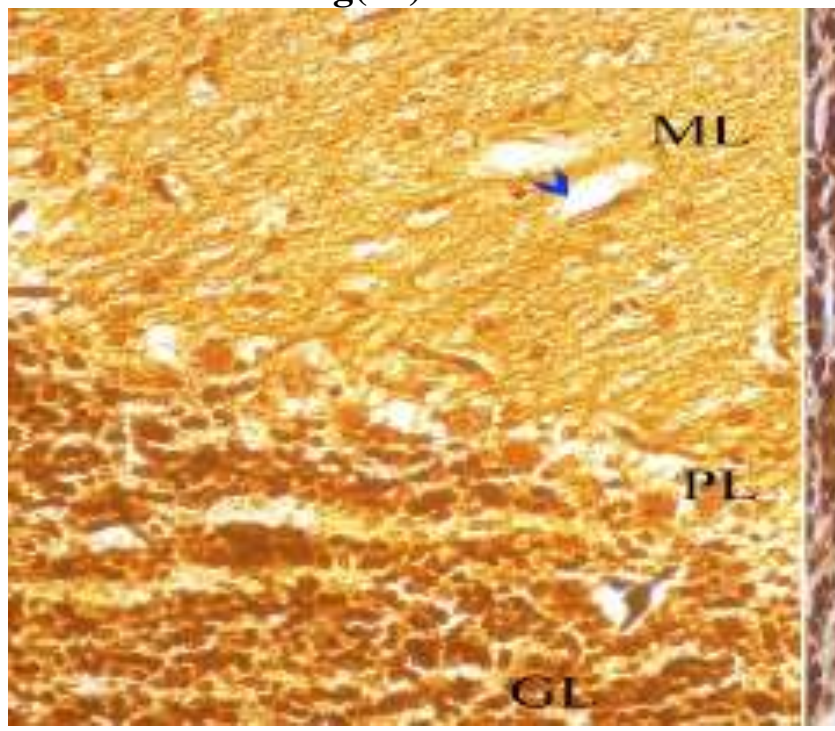

Fig. (6a)

A photomicrograph of a section in the cerebellum from a rat of the positive control group show:

6a: The three layers of the cerebellar cortex; molecular layer (ML) containing

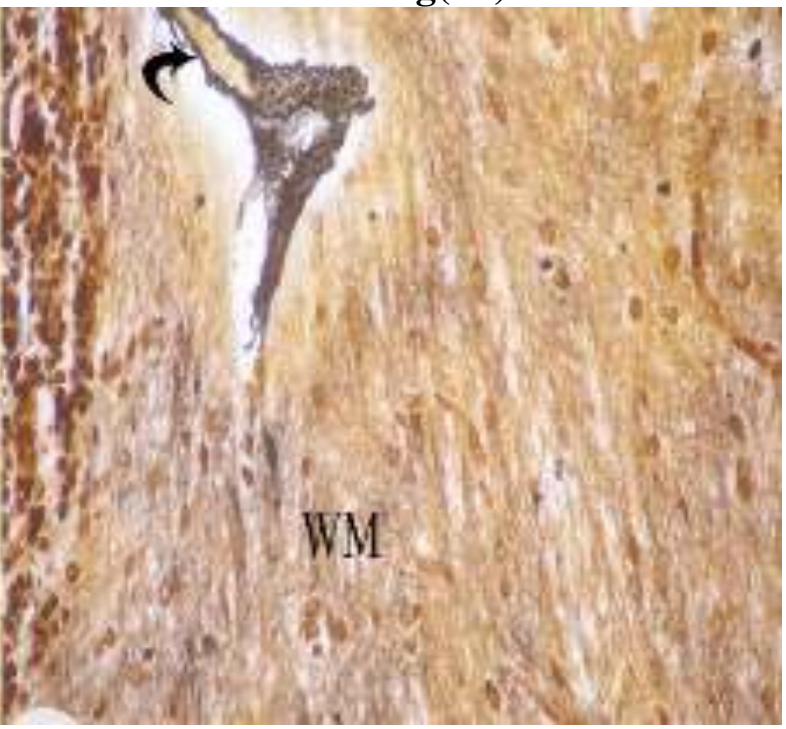

dendriticbranches of Purkinje cells, Purkinje cell layer (PL) with large flask-shaped Purkinje cells, and granular layer (GL).

Fig,(6b): The fibers of white matter (WM). [Silver stain $\times$ 400]

(Fig.7a) 
7a-A photomicrograph of a section in the cerebellum from a rat of group IIIA (received ACR at dose of $8.5 \mathrm{mg} / \mathrm{kg}$ body weight for 4 weeks) showing: The cerebellar cortex; dendritic branches of Purkinje cells are seen in the molecular layer (ML), Purkinje cell layer

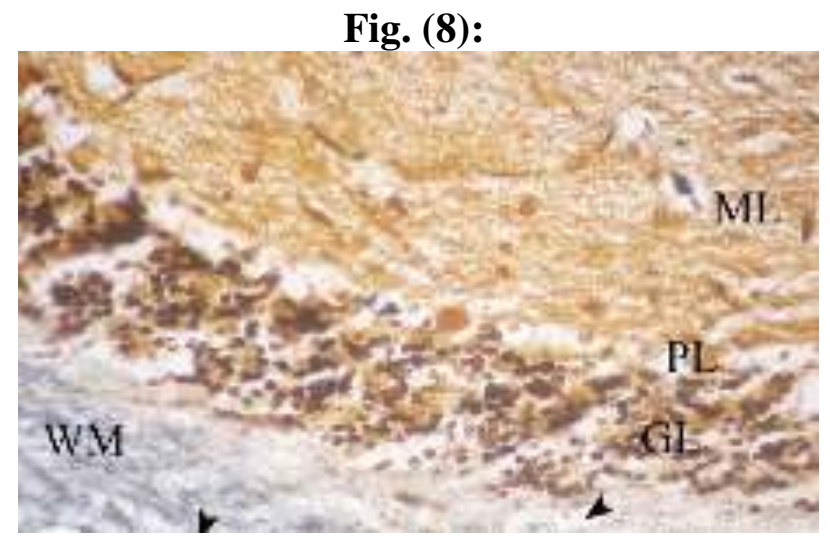

(PL) with loss of some Purkinje cells, and granular layer (GL). Note. wide perivascular spaces (blue arrow head).

Fig.7b)-The fibers of the white matter (WM). A blood vessel (curved arrow) is also seen. (Silver stain $\times \mathbf{4 0 0})$.

Fig. (10)

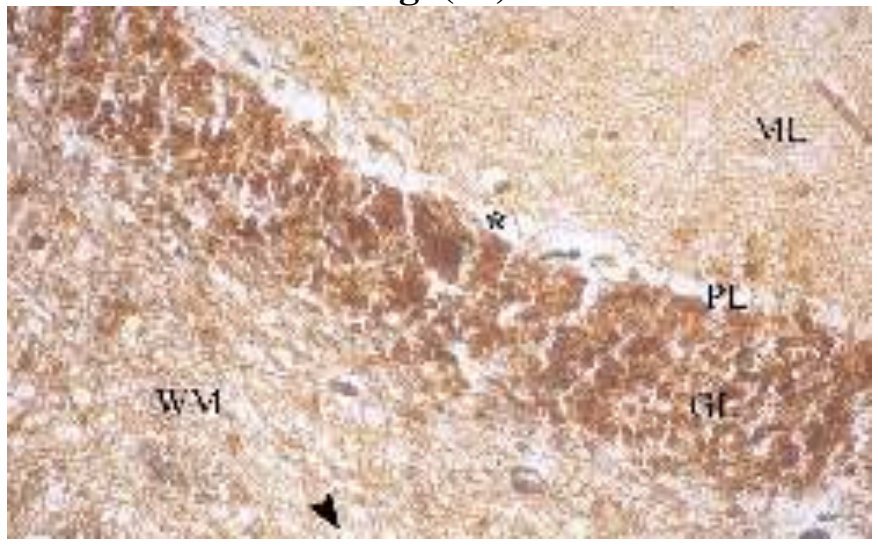

Fig. (8): A photomicrograph of a section in the cerebellum from a rat of group IIIB (received ACR at dose of $8.5 \mathrm{mg} / \mathrm{kg}$ body weight for 8 weeks) showing the cerebellar cortex; the molecular layer (ML) with dendritic branches of Purkinje cells, Purkinje cell layer (PL) with loss of most of Purkinje cells, and dgranular layer (GL) with loss of some granuler cells. The fibers of the white matter (WM) are seen with fragmentation of some of them (arrow head). [Silver stain $\times 400$ ]

Fig(.9): A photomicrograph of a section in the cerebellum from a rat of group IVA (received ACR at dose of $17 \mathrm{mg} / \mathrm{kg}$ body weight for 4 weeks) showing the cerebellar cortex; the molecular layer (ML) with dendritic branches
Fig. (8):

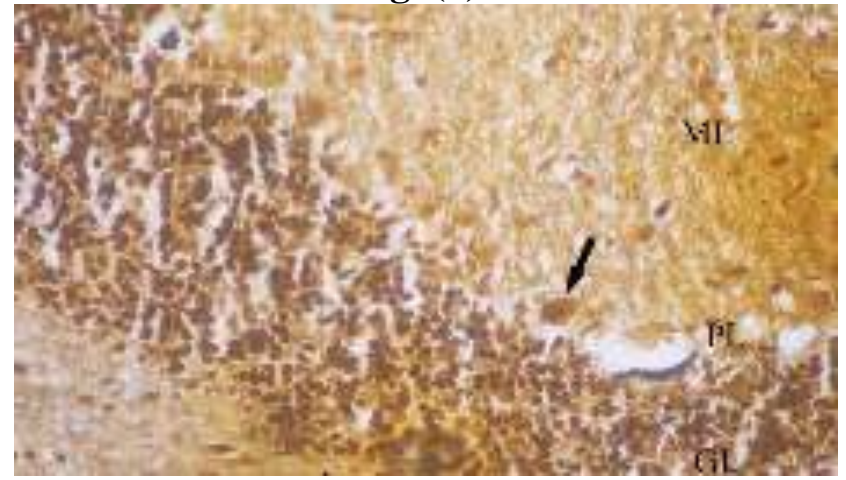


Fig. (11)

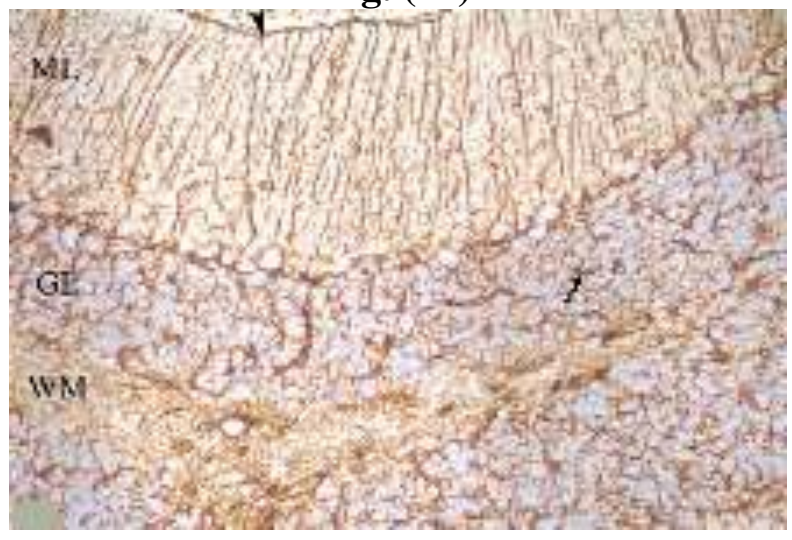

Fig. (11) Immunolocalization of GFAP in the from a rat of the positive control group showing GFAPpositive astrocytes; Bergmann-glia (arrow) in the molecular layer (ML), and true astrocytes (zigzag arrow) in the granular layer (GL). Note: the endfeet of Bergmann-glia (arrow head) and white matter (WM). [Immunoperoxidase X200]

Fig. (13

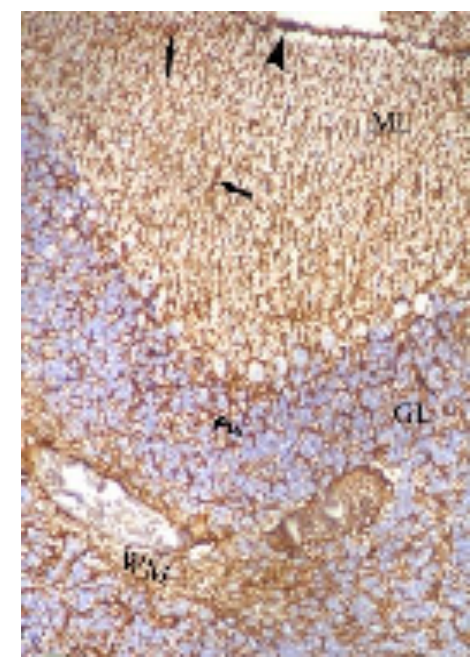

Fig. (13 ): Immunolocalization of GFAP (arrow) in the cerebellum from a rat of group IIIB (received ACR at dose of $8.5 \mathrm{mg} / \mathrm{kg}$ bw for 8 weeks) showing GFAP-positive astrocytes in molecular layer (ML) (arrow), granular layer (GL) (zigzag arrow), endfeet of Bergmann-glia (arrow head), and white matter (WM). They appear greater in number, with multiple thick processes and abundant distribution. [Immunoperoxidase X200\}
Fig. (12):

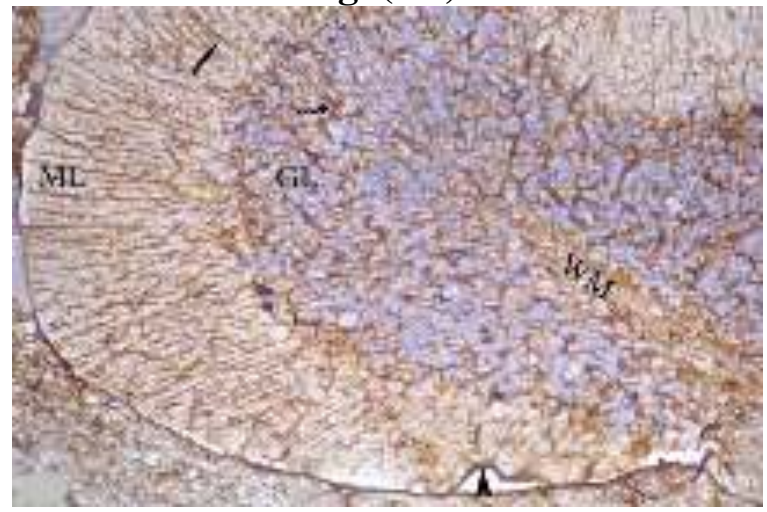

Fig. (12 ): Immunolocalization of GFAP in the cerebellum from a rat of group IIIA (received ACR at dose of $8.5 \mathrm{mg} / \mathrm{kg}$ bw for 4 weeks) showing GFAPpositive astrocytes in the molecular layer (ML) (arrow), granular layer (GL) (zigzag arrow), endfeet of Bergmann-glia (arrow head), and white matter (WM). They appear greater in number, with multiple thick processes.

\section{[Immunoperoxidase X200}

Fig. (14):

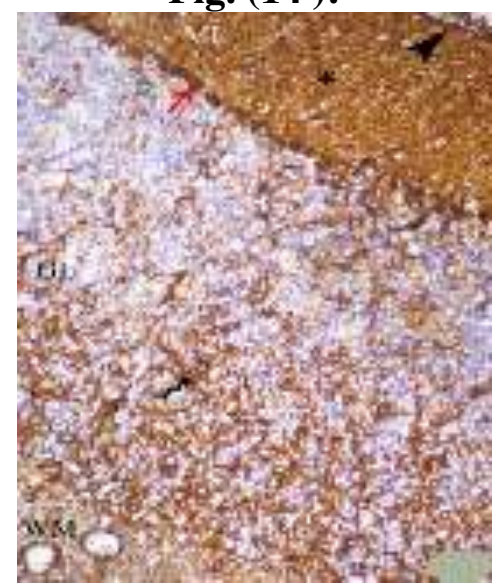

Fig. (14 ): Immunolocalization of GFAP in the cerebellum from a rat of group IVA (received ACR at dose of $17 \mathrm{mg} / \mathrm{kg}$ bw for 4 weeks) showing abundant distribution of GFAP-positive astrocytes in all layers; molecular (*), Purkinje cell (red arrow), granular (zigzag arrow) and white mater (WM). Note: the endfeet of Bergmann-glia (arrow head). [Immunoperoxidase X200] 
Fig. (15):

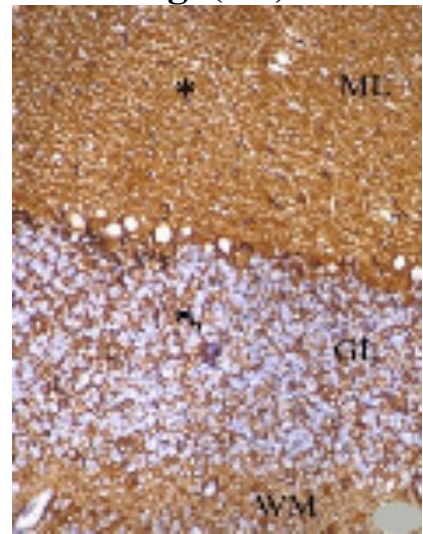

Fig. (15 ): Immunolocalization of GFAP (arrow) in the cerebellum from a rat of group IVB (received ACR at dose of $17 \mathrm{mg} / \mathrm{kg}$ bw for 8 weeks) showing abundant distribution of GFAP-positive astrocytes in all layers; molecular (*), granular (zigzag arrow) and white mater (WM) [Immunoperoxidase X200]

\section{DISCUSSION}

The concern about the possibility of ACR accumulation and its harmful on long term was recently raised and it was a priority for food safety issues to understand the health hazards following exposure to food-borne acrylamide, especially at low levels (Adewale et al., 2015 and Raju et al., 2015). The neurotoxic properties of acrylamide have been studied most because these are the only toxic effects that have been shown in humans related to occupational exposure (Erkekoglu and Baydar, 2014). So the aim of this work was to: Study the potential neurotoxic effects of acrylamide on the cerebellum.

Results of the present study revealed that, administration of ACR to rats at a dose of 8.5 $\mathrm{mg} / \mathrm{kg}$ and a dose of $17 \mathrm{mg} / \mathrm{kg}$ for either 4 weeks or 8 weeks had resulted in significant increase in landing hind limb foot splay and gait score when compared with those of control group. That increase in landing hind limb foot splay and gait score became more evident at the end of experimental period. The recorded landing hind limb foot splay and gait score in both groups after 8 weeks were significantly higher than those recorded after 4 weeks, indicating that this increase was a time dependent.
That increase in landing hind limb foot splay and gait score was also a dose dependent, as the previous parameter in rats received $17 \mathrm{mg} / \mathrm{kg}$ ACR were significantly higher than those of rats received $8.5 \mathrm{mg} / \mathrm{kg}$ ACR for the same period. Moreover, there was a strong, positive correlation between hind limb foot splay and gait score. Increases in foot splay were correlated with increases in gait score.

These results are consistent with Lopachin et al. (2002) who recorded significant progressive increase In both landing hind limb foot splay and gait sore of rats received $21 \mathrm{mg}$ $/ \mathrm{kg}$ per day ACR at end point ( day 40).Moreover, Lehning et al.(2002) found a time and dose dependent significant progressive increase in gait sore of rats received either 21 or $50 \mathrm{mg} / \mathrm{kg}$ per day ACR at end point ( day 38). Cumulative neurotoxicity of ACR also documented by Erkekoglue and Baydar,(2014), who informed the magnitude of toxic effect of acrylamide depend on the duration of exposure and the total exposure dose. On the other hand shi et al . (2012) found non-significant effect of ACR on both landing hind limb foot splay and gait score of rats received $5 \mathrm{mg} / \mathrm{kg}$ ACR for 4 weeks, that is may be attributed small dose and short duration testing. 
It is known that the function of the cerebellum is motor control as well as production and storage of motor memories it plays a major role in the generation of appropriate patterns of limb movements, dynamic regulation of balance, and adaptation of posture and locomotion. Ataxia is a pathological coordination failure that involves functional disturbances in cerebellar circuits. (shi et al., 2012). The neurological defect in form of (ataxia, foot splay, hind limb skeletal muscle weakness is mainly attributed to Cerebellar lesions in animals (Morton and Bastian, 2004).

Results of the present work showed a significant weakening in motor function of treated rats represented by both significant increase in gait score and hind limb foot splay) that is could be explained by the associated cerebellar pathological finding According to Yu et al. (2005) and shi et al. (2012) landing hind limb foot splay and gait score tests are the most sensitive indices for assessment of neurotoxicity, increases in(distance of foot splay and score of gait) are reliable indicators of neurotoxicity. Such behavioral and physiological indices evaluate the functional consequences of disruption of neuronal communications (Moser, 2011).

\section{Histopathological Changes of cerebellum:}

Microscopic examination of $\mathrm{H} \& \mathrm{E}$ stained cerebellar sections of rats received $8.5 \mathrm{mg} / \mathrm{kg}$ ACR for 4 weeks (group IIIA), revealed prominent perineural spaces around cells in the molecular layer, Purkinje cell layer, and granular layer. Some Purkinje cells appeared with abnormal morphology, they appeared to have dark stained nuclei while administration of the same dose $(8.5 \mathrm{mg} / \mathrm{kg}$ ACR) for longer duration ( 8 weeks) (group IIIB) result in more prominent histopathological changes in form of loss of some of Purkinje cells These changes progressed on administration of $17 \mathrm{mg} / \mathrm{kg}$ ACR for either 4 weeks or 8 weeks (group IVA, IVB) in the form of selective loss of most of Purkinjie cells.

These results are consistent with Lehning et al. (2002) who reported selective loss of of
Purkinje cells in cerebellum of rats received either 21 or $50 \mathrm{mg} / \mathrm{kg} / \mathrm{ACR}$. Shi et al.(2012) found Purkinje cells damage in cerebellum of rats intoxicated at different daily ACR doserates 15 or $30 \mathrm{mg} / \mathrm{kg}$.

Purkinje cells are large, GABAergic neurons, which serve as the sole output neurons of the cerebellar cortex.. As the only efferent neurons in the cerebellum, Purkinje cell death results in a functional lesion of the cerebellum. Purkinje cells are associated with movement coordination and regulation of body balance (Shi et al., 2012). Therefore, our results that revealed, ACR-induced ataxia and increase distance of hind limb splay are probably attributed to damage of the Purkinje cells

The molecular mechanism of Purkinje neuron damage during ACR intoxication is not known. ACR might cause Purkinje cell injury by an indirect mechanism. Neuronal calcium may play a role in neuronal survival as well as in apoptosis, pathological neuronal, degeneration and necrosis Sustained increase in intracellular calcium levels, , have been shown to correlate with increased protein and lipid degradation, which progresses to cell death (Furukawa et al., 2012).

In the current work, examination of silver stained cerebellar sections of rats received low dose of ACR for 4 weeks showed loss of some Purkinje cell. In addition, other groups received low dose for 8 weeks or rats that received high dose for either 4 or 8 weeks showed loss of most Purkinje cell and the fibers of the white matter were seen also with progressive fragmentation that indicated obvious axon degeneration.

The results of present work were consistent with Lehning et al. (2005) who found that ACR caused axon degeneration at low subchronic exposure rates (10-20 $\mathrm{mg} / \mathrm{kg} /$ day).in addition, Lopachin (2005) demonstrated that, The morphological hallmark of ACR toxic neuropathy was considered to be distal nerve terminal and preterminal axon swellings of the longest myelinated fibers. According toLopachin and Gavin, (2015). Axon degeneration was often preceded by 
multifocal paranodal giant axonal swellings and, depending upon the toxicant, these swellings contained accumulations of cytoskeletal components (e.g,neurofilaments), fragments of the smooth endoplasmic reticulum and degenerating mitochondria According to lopachin et al. (2003) silver stain method is characterized by higher sensitivity, specificity and reproducibility which make it an important tool for identification and tracking degenerating axons and other neuronal structures in brain and spinal cord.

The result of the present work revealed that, immunolocalization of glial fibrillary acidic protein (GFAP) in the cerebellum of rats received low dose ACR for either 4 or 8 weeks showed GFAP-positive astrocytes in the molecular layer, granular layer and white matter, while Immunolocalization of (GFAP) in the cerebellum of rats received high dose ACR for either 4 or 8 weeks showed more abundant distribution of GFAP-positive astrocytes in the molecular layer, granular layer and white matter .

These results were consistent with Shi et al. (2012) who found upregulation of the expression of GFAP in the cerebellum of rats received $15 \mathrm{mg} / \mathrm{kg}$ ACR.

Advances in neuroimmunology and protein purification methodology have led to the identification of nervous-system specific proteins. Their intimate relationship to the cellular and functional heterogeneity of the nervous system, makes these proteins ideal biochemical markers for the detection and characterization of neurotoxicity (O'Callaghan and Sriram, 2005).

Astrocytes glial cells play an important role in the onset and development of various injuries or diseases in the CNS. Glial fibrillary acidic protein is an important component of cystoskeleton, also, it is the main constituent of an intermediate filament in the cytoplasm of astrocytes. Increased expression of GFAP considered to be an early marker of brain injury (Tanaka et al, 2002).

According to Shi et al. (2012) up-regulation of GFAP expression in the cerebellar cortex in
ACR neurotoxicity is a reactive increase of astrocytes in response to the Purkinje cells damage.

Results of the current work revealed non significance difference between control and treated group in cerebellar tissue area percentage, however, there was a strong positive correlation between foot splay and area percentage, and a moderate correlation between gait score and area percentage respectively. A multiple linear regression was calculated to predict the extent of structural cerebellar lesion induced by acrylamide in rats based on changes in hind limb foot splay and gait score. It was found that, the area percentage increased by $8.939 \%$ for each one degree increase in the gait score, and $5.942 \%$ for each $1 \mathrm{~cm}$ increase in the hind limb foot splay and a significant regression was found.

Conclusions: results of the present work clarified neurotoxic effects of ACR which evidenced by impairment of motor control of rats received ACR (increase in gait score and landing hind limb foot splay), that impairment were attributed to histopathological change in cerebellar section of treated rats in form of cell loss, axonapathy and gliosis, all neurobehavioral and histopathological finding were both time and dose dependent.

\section{Recommendations:}

On the light of the results of the present study, the following guidelines are recommended: Widespread public education regarding health hazards of Acrylamide. Regular monitoring for functions of nervous system for people exposed to acrylamide in their daily work or those who consume food known to have high level of acrylamide.

Acknowledgement: We acknowledge Zagazig Scientific and Medical Research Center of the Faculty of Medicine for its support.

\section{REFERENCES}

1. Adewale, O.O.; Brimson, J.M.; Odunola, O.A.; et al., (2015): The Potential for Plant Derivatives against Acrylamide Neurotoxicity. Phytother. Res., 29(7): 978985.

2. Bancroft, J. and Stevens, A. (1996): Theory and practice of histological technique (fourth 
ed.) .Churchill, Livingston, Edin burgh, London, Melbourne and New York pp. 5056.

3. Changes in the neurofilament protein of rat cerebrum fractions. Neurochem Res. 30(9):1079-1085.

4. Coons, A. and Kaplan, M. (2009): Localization of antigen in tissue cells; improvements in a method for the detection of antigen by means of fluorescent antibody. J. Exp. Med.; 1; 91(1):1-13.

5. De Olmos, J.D, Beltramino, C.A. and de Lorenzo, S. (1994): Use of an amino-cupricsilver technique for the detection of early andsemiacute neuronal degeneration caused by neurotoxicants, hypoxia,and physical trauma. Neurotoxicol Teratol 16: 545-561.

6. Erkekoglu, P. and Baydar, T. (2010): Toxicity of acrylamide and evaluation of its exposure in baby foods. Nutr. Res. Rev., 23: 323-333.

7. Erkekoglu, P. and Baydar, T. (2014): Acrylamide neurotoxicity. Nutritional. Neuroscience, 17(2): 49-57.

8. Furukawa,S.; Wingenfeld,L.; Takaya,A.; et al., (2012): Purkinje cell injury caused by acrylamide, Forensic Res., 82:121-132.

9. Ischemia in GFAP deficient mice. Journal of Neuroscience Research, 67(1): 11-20.

10. Institute of labratoey animal resources, commission on life sciences, National Research Council (2011): Guide for the care of use lab animals

11. Kumar, E.; Banda, S. and Prakash, T. (2014): Mitigative effect of hesperidin on acrylamide proved neurotoxicity in rats. I.J.P.R.D., 5(12): 86-90.

12. Lehning, E.J.; Balaban, C.D.; Ross, J.F.; et al., (2002): Acrylamide neuropathy I. Spatiotemporal characteristics of nerve cell damage in rat cerebellum. Neurotoxicology, 23(1): 397- 414.

13. Lehning, E.J.; Balaban, C.D.; Ross, J.F.; et al., (2005): Acrylamide neuropathy. III. Spatiotemporal characteristics of nerve cell damage in forebrain. Neurotoxicology, 24(1): 125- 136.

14. LoPachin, R. M. (2005): Acrylamide in food: the discovery and its implications. In: Friedman, Mottram (Eds.), Chemistry and safety of acrylamide in food. Springer Science Business Media, Inc, pp.1-20.

15. LoPachin, R.M. and Gavin, T. (2015): Toxic neuropathies: Mechanistic insights base $\mathrm{d}$ on a chemical perspective. Neurosci. Lett., 596: 78-83.

16. LoPachin, R.M.; Balaban, C.D.; Ross, J.F.; et al., (2003): Acrylamide axonopathy revisited. Toxicol. Appl. Pharmaco., 188: 135-153

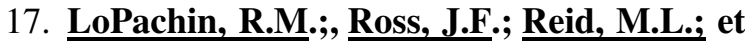
al

(2002): Neurological evaluation of toxic axon opathies in rats: acrylamide and 2,5-

hexanedione. Neurotoxicology. 23(1):95110.

18. Morton, S. M. and Bastian, A.J. (2004): Cerebellar control of balance and locomotion. The Neuroscientist, 10 (3)247259.

19. Moser,V.C. (2011): Functional assays for neurotoxicity testing. Toxicologic Pathology, 39: 36-45, 2011

20. O'Callaghan, J.P. and Sriram, K. (2005): Glial fibrillary acidic protein and related glial proteins as biomarkers of neurotoxicity. Expert opinion on drug safety, 4(3):433-442.

21. Papadopulos, F., Spinelli, M., Valente, S., Foroni, L., Orrico, C., Alviano, F., \& Pasquinelli, G. (2007): Common tasks in microscopic and ultrastructural image analysis using ImageJ. Ultrastructural pathology, 31(6), 401-407.

22. Raju, J.; Roberts, J.; Taylor, M.; et al., (2015): Toxicological effects of short-term dietary acrylamide exposure in male F344 rats. Environ. Toxicol. Pharmacol., (1): 85-92.

23. Santhanasabapathy, R.; Vasudevan, S.; Anupriya, K.; et al., (2015): Farnesol quells oxidative stress, reactive gliosis and inflammation during acrylamide-induced neurotoxicity: Behavioral and biochemical evidence. Neuroscience, 12(308): 212-227.

24. Shi, J.; Ma, Y.; Zheng, M.;_et al., (2012): Effect of sub-acute exposure to acrylamide on GABAergic neurons andastrocytes in weaning rat cerebellum. Toxicol. Ind. Health, 28(1):10-20.

25. Tanaka, H.; Katoh, A.; Oguro, K.; et al., (2002): Disturbance of hippocampus longterm potentiation after transient

26. Yu, S.F.; Zhao, X.L.; Zhang, T.L.; et al., (2005): Acrylamide induced

27.

evesque, R. (2007): SPSS Programming and Data Management: A Guide for SPSS and SAS Users; 6(2): 159-177. 


\section{الملخص العربي}

\section{دراسة الآثار السمية العصبية المحتملة للأكريلاميد على المخيخ فى الجرذان البيضاء البالغة

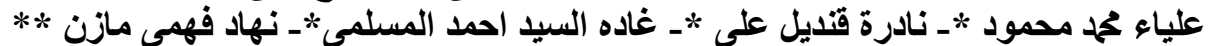

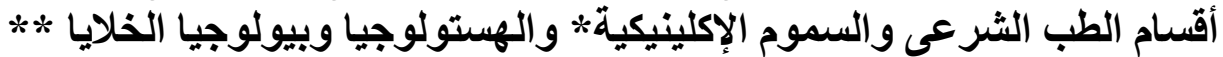

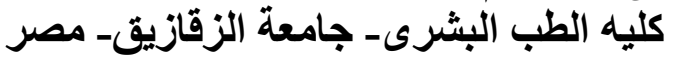

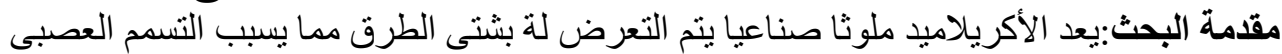

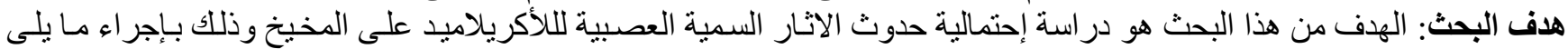

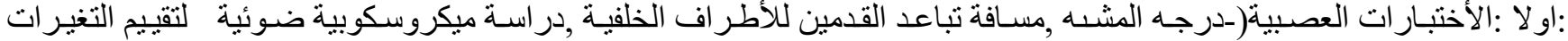

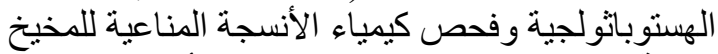

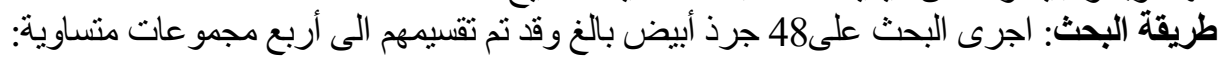

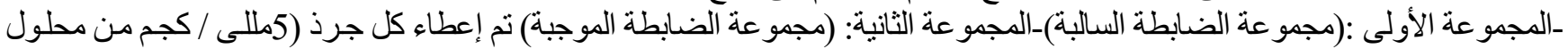

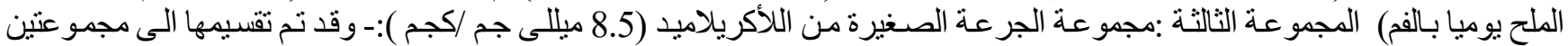

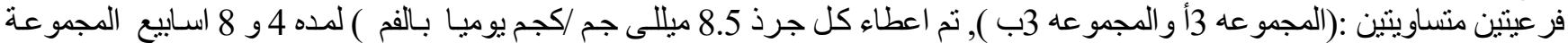

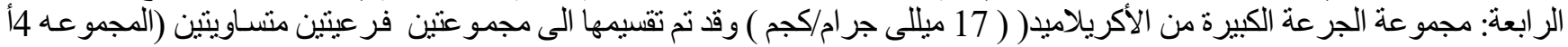

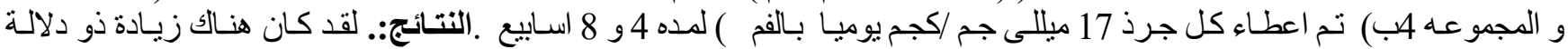

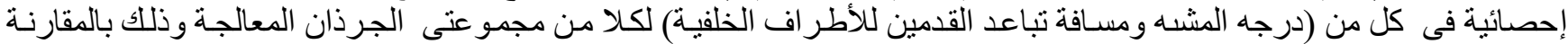

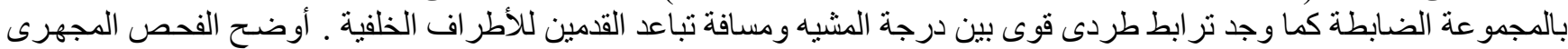

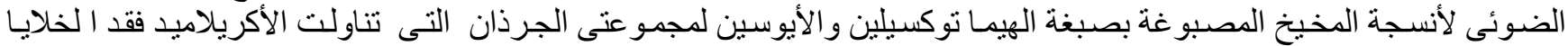

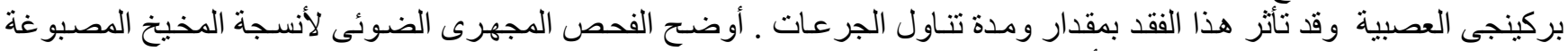

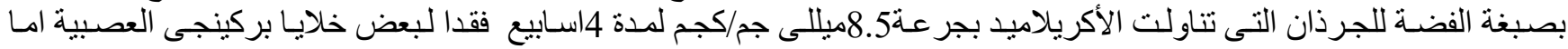

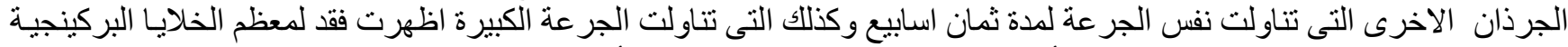

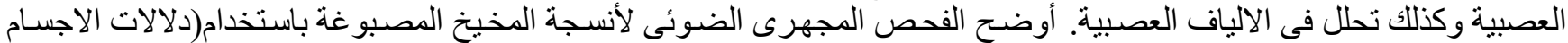

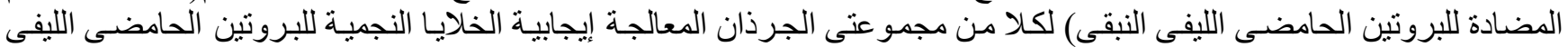

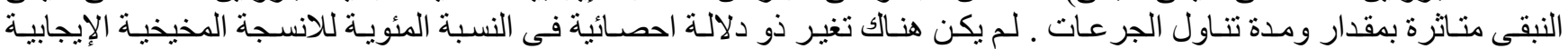

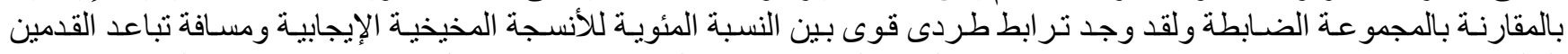

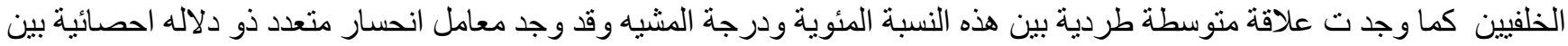

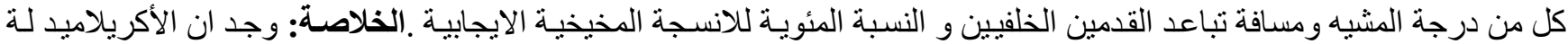

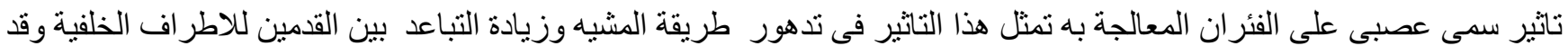

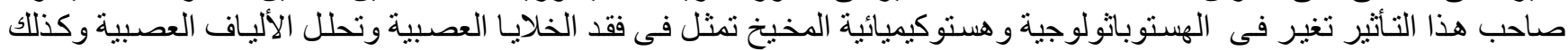

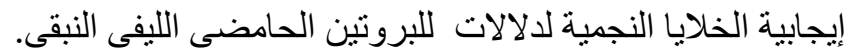
التوصيات : ينصح بزيادة الوعي العام بشأن المخاطر الصحية الناتجة عن التعرض للأكريلاميد 